\title{
Lymphocyte Activation and Hepatic Cellular Infiltration in Immunocompetent Mice Infected by Dengue Virus
}

\author{
Hsuen-Chin Chen, ${ }^{1}$ Show-Yun Lai, ${ }^{1,7}$ Jui-Min Sung, ${ }^{1}$ Shu-Hwae Lee, ${ }^{8}$ Yu-Chin Lin, ${ }^{1}$ Wei-Kung Wang, ${ }^{2}$ \\ Yee-Chun Chen, ${ }^{3,5}$ Chuan-Liang Kao, ${ }^{4}$ Chwan-Chuen King, ${ }^{6}$ and Betty A. Wu-Hsieh ${ }^{1 *}$ \\ ${ }^{1}$ Graduate Institute of Immunology, College of Medicine, National Taiwan University, Taiwan \\ ${ }^{2}$ Graduate Institute of Microbiology, College of Medicine, National Taiwan University, Taiwan \\ ${ }^{3}$ Department of Medicine, College of Medicine, National Taiwan University, Taiwan \\ ${ }^{4}$ Graduate Institute of Medical Technology, College of Medicine, National Taiwan University, Taiwan \\ ${ }^{5}$ Department of Internal Medicine, Division of Infectious Diseases, National Taiwan University Hospital, Taiwan \\ ${ }^{6}$ Institute of Epidemiology, College of Public Health, National Taiwan University, Taiwan \\ ${ }^{7}$ Bureau of Food and Drug Analysis, Department of Health, Taiwan \\ ${ }^{8}$ Animal Health Research Institute, Council of Agriculture, Executive Yuan, Taiwan
}

Activation and expansion of dengue virus-specific T cells and abnormal liver functions in dengue patients have been documented. However, it remains to be determined whether T cells are involved in the pathogenic mechanism of dengue virus infection. In this study, immunocompetent C57BL/6 mice were employed to study dengue virus-induced T cell activation. Mice were inoculated with $10^{8} \mathrm{PFU}$ dengue virus serotype 2 strain 16681 by the intravenous route. Dengue viral core RNA was detected by RT-PCR in mouse serum, liver, spleen, and brain at different time points after infection. Splenic T cells were activated as evidenced by their expression of CD69 and $O$ glycosylated CD43 at as early as day 3 after infection. Splenic T cell expression of $\mathrm{O}$-glycosylated $\mathrm{CD} 43$ and IFN- $\gamma$ production coordinately peaked at day 5 . Coincided with the peak of splenic T cell activation was hepatic lymphocyte infiltration and elevation of liver enzymes. Flow cytometric analysis revealed the infiltrating $\mathrm{CD}^{+}$ T cell to $\mathrm{CD} 4^{+} \mathrm{T}$ cell ratio was $5 / 3$. After a second inoculation of dengue virus, hepatic T cell infiltration and liver enzyme levels increased sharply. The infiltrating hepatic $\mathrm{CD} 8^{+} \mathrm{T}$ cell to $\mathrm{CD} 4^{+} \mathrm{T}$ cell ratio increased to 5.8/1. A strong correlation was found between $T$ cell activation and hepatic cellular infiltration in immunocompetent mice infected with dengue virus. The kinetics of liver enzyme elevation also correlated with that of $T$ cell activation. These data suggest a relationship between $T$ cell infiltration and elevation of liver enzymes. J. Med. Virol. 73:419-431, 2004. (C) 2004 Wiley-Liss, Inc.
KEY WORDS: dengue virus; immunocompetent mice; $T$ cell activation; hepatic cellular infiltration

\section{INTRODUCTION}

Dengue virus is a single positive-stranded RNA virus that belongs to the family Flaviviridae. Four antigentically related dengue viral serotypes cause a spectrum of clinical illness and significant mortality and morbidity throughout the tropics and subtropics [Monath, 1994]. In the year 1998, dengue fever became the most important tropical infectious disease next to malaria. There are an estimated 50-100 million dengue infections, $250,000-500,000$ cases of dengue hemorrhagic fever and 25,000 deaths annually [Gubler, 1998; Guzman and Kouri, 2002].

It has been reported that soluble $\mathrm{CD} 4(\mathrm{sCD} 4)$, soluble CD8 (sCD8), and soluble IL-2 receptor (sIL-2R) are found in the sera of children with dengue hemorrhagic fever [Kurane et al., 1991]. The acute sera of patients

Grant sponsor: National Health and Research Institute (ROC); Grant number: NHRI-CN-CL8903P; Grant sponsor: National Taiwan University Hospital; Grant numbers: NTUH 90A12, 91A24.

*Correspondence to: Betty A. Wu-Hsieh, Graduate Institute of Immunology, National Taiwan University, College of Medicine, No. 1 Jen-Ai Road, Section 1, Taipei, Taiwan.

E-mail: wuhsiehb@ha.mc.ntu.edu.tw

Accepted 15 March 2004

DOI 10.1002/jmv.20108

Published online in Wiley InterScience

(www.interscience.wiley.com) 
with dengue fever contained higher than normal levels of sCD4 and sIL-2R but not sCD8. The levels of sCD8, sCD4, and sIL-2R in dengue hemorrhagic fever patients are significantly higher than in dengue fever patients on days 3-4 after onset of fever. Recently, Zivna et al. [2002] compared the frequency of peptide-specific T cells in subjects who experienced dengue hemorrhagic fever as a result of secondary infection and those who had dengue fever as a secondary infection, and found that the frequency of specific T cells were higher in the former than the latter. These findings suggest that the activation and expansion of dengue virus-specific $\mathrm{T}$ cells, especially that of $\mathrm{CD}^{+} \mathrm{T}$ cells is greater in subjects with more severe clinical syndrome and support the hypothesis that activation of dengue virus-specific $T$ cells plays an important role in the pathogenesis of dengue hemorrhagic fever [Zivna et al., 2002]. Therefore, it is critical to understand the kinetics of $\mathrm{T}$ cell activation in relation to the pathogenesis of dengue. Such a study is best carried out in experimental animals.

Several small animal models have been established to study dengue and to test potential dengue vaccines. Early attempts by Falgout et al. [1990] showed that intracerebral inoculation of $\mathrm{LD}_{100}$ and $\mathrm{LD}_{50}$ dengue virus into $\mathrm{BALB} / \mathrm{c}$ mice produced encephalitis. SCID mice engrafted with human peripheral blood lymphocytes (hu-PBL-SCID), human K562 or HepG2 cells were also used to study dengue virus infection [Wu et al., 1995; Lin et al., 1998; An et al., 1999]. In the former, huPBL-SCID model dengue virus serotype-1 Western Pacific strain 74 was used and the virus was recovered at low rates from different organ systems. In the latter, HepG2-SCID model, animals showed neurological signs after injection with dengue virus serotype-2 strain Tr1751 and died at 2 weeks post-infection. A/J mice infected intravenously with dengue virus serotype-2 strain PL-046 developed transient thrombocytopenia and produced anti-platelet antibody after primary as well as secondary infection [Huang et al., 2000]. AG129 mice with defects in IFN- $\alpha, \beta, \gamma$ receptor genes infected with mouse-adapted dengue virus serotype- 2 of New Guinea C strain experienced transient viremia and died within 12 days of infection [Johnson and Roehrig, 1999]. Each of these animal models has its merit, but none of them has been used to evaluate $\mathrm{T}$ cell response to dengue virus.

In this study, immunocompetent C57BL/6 mice were employed to investigate $\mathrm{T}$ cell response to dengue virus infection and to study the role of $\mathrm{T}$ cells in immunopathogenesis of dengue disease. Mice were infected with high titers of dengue virus serotype-2 strain 16681 , originally isolated from a dengue hemorrhagic fever patient from Thailand [Russell et al., 1967]. RT-PCR and real-time RT-PCR revealed dengue viral RNA in the sera and various tissues of the infected mice. T cells in the infected mice were activated and functionally active, as evidenced by production of IFN- $\gamma$. CD8 $\mathrm{T}$ cells constituted the majority of activated T cells. Coincided with the kinetics of $\mathrm{T}$ cell activation was liver enzyme elevation and hepatic $\mathrm{T}$ cell infiltration. Taken together, the results of this study point to the possibility of T cellmediated liver damage in dengue disease.

\section{MATERIALS AND METHODS}

\section{Virus}

Dengue virus serotype-2 strain \#16681 was used throughout this study. Dengue virus serotype-2 \#16681 was originally isolated from a Thai patient who suffered dengue hemorrhagic fever [Russell et al., 1967]. The virus was propagated in insect cell line C6/36 cultured in DMEM (Gibco-BRL, Gaithersburg, MD) and M\&M (Sigma-Aldrich, St. Louis, MO) (1:1 ratio) containing $2 \%$ heat-inactivated fetal calf serum (Biological Industries, Kibbutz Beit Haemek, Israel) at $28^{\circ} \mathrm{C}$. The virus titer was at $\geq 2 \times 10^{8} \mathrm{PFU}$ per ml. C6/36 culture supernatant (Mock) and UV-inactivated virus (UV-DV) were used as controls. Virus stocks were inactivated by UV treatment at $50 \mathrm{~mJ} / \mathrm{cm}^{2}$ in $30 \mathrm{sec}$ by Spectrolinker XL-1000 crosslinker (Spectronics Corporation, Westbury, NY). Loss of infectivity was confirmed by plaque assay.

\section{Infection}

C57BL/6 mice were obtained from the Jackson Laboratory (Bar Harbor, ME) and bred at National Taiwan University College of Medicine Laboratory Animal Center. Mice at 4-5 weeks of age were injected intravenously with $1 \times 10^{8} \mathrm{PFU}$ in $0.5 \mathrm{ml}$ volume. Tissues were removed from mice at different time points after infection as indicated in the legend of each figure. Mice were bled from the orbital vein and sera were used for RT-PCR, real-rime RT-PCR assays, and liver enzyme determinations. In some experiments, mice were given a second inoculation of virus $\left(1 \times 10^{8} \mathrm{PFU}\right)$ at day 7 after primary infection. Mice injected with $0.5 \mathrm{ml}$ of UVinactivated virus, mock $\mathrm{C} 6 / 36$ culture supernatant, or PBS were used as controls.

\section{Reagents}

Immunological reagents including: conjugated antiCD4 (clone GK1.5), anti-CD8 (clone 53-6.7), anti-CD69 (clone H1.2F3), anti-CD44 (clone IM7), and IFN- $\gamma$ (clone XMG 1.2) antibodies and IFN- $\gamma$ ELISA kits were obtained from eBioscience (La Jolla, CA). Anti-Oglycosylated CD43 (clone 1B11) was obtained from BD PharMingen (San Diego, CA). RPMI 1640, HEPES buffer, L-glutamine, sodium pyruvate, non-essential amino acids, penicillin/streptomycin were purchased from Gibco-BRL. 2-Mercaptoethanol was purchased from Sigma-Aldrich.

\section{Real-Time RT-PCR Assays}

Real-time RT-PCR assay was employed to quantify dengue virus in sera [Wang et al., 2002]. Briefly, dengue viral RNA was isolated from serum using the QIAamp viral RNA mini kit (Qiagen, Hilden, Germany). An aliquot $(2.5 \mu \mathrm{l})$ of purified RNA and known amounts of positive-sense RNA $(2.5,25,250,2,500,25,000$, and 
$2,500,000$ copies) were subjected to real-time RT-PCR using the designed primers (d2C16A, 5'-GCTGAAACGCGAGAGAAACC- $3^{\prime}$ and d2C46B, $3^{\prime}$-TCCCTGCTCCTGGTIATTTTGAC-5') and probe (VICd2C38B, 3'-TGTCGACTGTTTCTCTAAGAGTGAACCTTACGA-5'), and the Taqman one-step RT-PCR master mix reagent kit (PE Biosystems, Foster City, CA). The amplification condition was $48^{\circ} \mathrm{C}$ for $30 \mathrm{~min}$ and $95^{\circ} \mathrm{C}$ for $10 \mathrm{~min}$, followed by 40 cycles of $95^{\circ} \mathrm{C}$ for $15 \mathrm{sec}$ and $60^{\circ} \mathrm{C}$ for $1 \mathrm{~min}$, as recommended by the manufacturer. The ABI Prism 7700 sequence detector was used to analyze the emitted fluorescence during amplification. A positive result is defined by the cycle number (CT value) required to reach the threshold, which is ten times the standard deviation of the mean baseline emission calculated for PCR cycles $3-15$. Since $2.5 \mu \mathrm{l}$ of the $50-\mu \mathrm{l}$ RNA elutes, which were derived from $100 \mu \mathrm{l}$ of serum, was used in each reaction, the number of dengue virus RNA copies per reaction was divided by $5 \mu \mathrm{l}(100 \mu \mathrm{l} \times 2.5 \mu \mathrm{l} / 50 \mu \mathrm{l})$ and multiplied by 1,000 to determine the number of RNA copies per $\mathrm{ml}$ of serum. The sensitivity of the assay is 2.5 copies of RNA per reaction, corresponding to 357 copies per $\mathrm{ml}$ of serum.

\section{Detection of Dengue Virus in Tissues by RT-PCR}

Spleen, liver, brain, and serum were collected from control as well as infected mice at days 1, 3,5, and 7 after infection. RNeasy mini kit (Qiagen) was used to extract RNA from $30 \mathrm{mg}$ of tissue. Tissue was homogenized in $600 \mu \mathrm{l}$ of RLT buffer with $0.1 \%$ of $\beta$-ME (2-mercaptoethanol) and RNA was extracted with $70 \%$ ethanol. RNA extract was filtered through RNeasy mini column (Qiagen) into collection tube by centrifugation for $15 \mathrm{sec}$ at $10,000 \mathrm{rpm}$. The RNA was washed with buffer RPE and DEPC water and stored at $-80^{\circ} \mathrm{C}$. The RNA was reverse transcribed and cDNA amplified in one reaction tube with primer set $\mathrm{C} 14 \mathrm{~A}$ and $\mathrm{C} 69 \mathrm{~B}$ and $\mathrm{RT} / \mathrm{Tag}$ mix (Gibco-BRL). The sequences of $\mathrm{C} 14 \mathrm{~A}$ and $\mathrm{C} 69 \mathrm{~B}$ are $5^{\prime}$ AATATGCTGAAACGCGAGAGAAACCGCG-3' (corresponding to genome positions $136-163$ of the DEN-2 Jamaica strain) and 5'-CCCATCTCTTCAGTATCCCTGCTGTTGG-3' (corresponding to genome positions 278-305 of the dengue virus serotype-2 Jamaica strain), respectively [Deubel et al., 1986; Wang et al., 2000]. They were designed to amplify a 170 -bp product in the $\mathrm{C}$ region of dengue viral RNA. The RT-PCR reaction took place in the following condition: $40 \mathrm{~min}$ at $55^{\circ} \mathrm{C}, 2 \mathrm{~min}$ at $94^{\circ} \mathrm{C}$ followed by 35 cycles of $45 \mathrm{sec}$ at $94^{\circ} \mathrm{C}, 45 \mathrm{sec}$ at $62^{\circ} \mathrm{C}$, and $45 \mathrm{sec}$ of $68^{\circ} \mathrm{C}$, then $5 \mathrm{~min}$ at $68^{\circ} \mathrm{C}$. The PCR products were diluted 1:500 and amplified by 40 cycles of PCR reaction $\left(45 \mathrm{sec}\right.$ at $94^{\circ} \mathrm{C}, 45 \mathrm{sec}$ at $62^{\circ} \mathrm{C}$, and $45 \mathrm{sec}$ at $68^{\circ} \mathrm{C}$, followed by $5 \mathrm{~min}$ at $\left.68^{\circ} \mathrm{C}\right)$ with $\mathrm{C} 22 \mathrm{~A}\left(5^{\prime}\right.$ GCGTGTCGACTGTACAACAG-3') and C63B (5'-GAGTGTTAGGGTGGTTGTCGT-3') primer set and Taq DNA polymerase (Klen Tag, St. Louis, MO). The nested RT-PCR products were loaded onto $2 \%$ agarose gel for separation. The size of nested RT-PCR products was $125 \mathrm{bp}$. HPRT gene was amplified as a control. The primer set for HPRT amplification was $5^{\prime}$-GTTGGATACAGGCCAGACTTTGTTG-3' and 5'-GAGGGTAGGCTGGCCTATGGCT- $3^{\prime}$. The molecular size for PCR product of HPRT was $352 \mathrm{bp}$.

\section{Immunostaining and Flow Cytometric Analysis of Cell Surface Marker}

One million of spleen cells were placed in the wells of V-bottomed 96-well plate. Cells were spun down at $4^{\circ} \mathrm{C}$, supernatants removed, and washed two times in staining buffer. Phycoerythrin (PE)-conjugated anti-CD4 or PE-conjugated anti-CD8 and fluorescein isothiocyanate (FITC)-conjugated anti-CD69, FITC-conjugated antiCD43 activation-associated glycoform, or FITC-conjugated anti-CD44 antibodies at final concentration of $1 \mu \mathrm{g} / \mathrm{ml}$ were added to the wells. Thirty minutes after incubation at $4^{\circ} \mathrm{C}$, the cells were spun down and washed. The cell pellets were resuspended in staining buffer containing $1 \%$ paraformaldehyde. Cells were acquired by FACSCalibur (BD Biosciences, San Jose, CA). Data were analyzed by CellQuest.

\section{IFN- $\boldsymbol{\gamma}$ Enzyme-Linked Immunoabsorbent Assay}

Spleen cells were harvested from uninfected control mice and mice inoculated with mock supernatant, UVinactivated virus or live dengue virus at different time points after inoculation. Single cell suspension was prepared and the red cells were lysed by treatment in $0.85 \%$ Tris- $\mathrm{NH}_{4} \mathrm{Cl}$ buffer. Splenocytes at $5 \times 10^{5}$ in $100 \mu \mathrm{l}$ of RPMI medium containing $20 \mathrm{mM}$ of HEPES, Lglutamine, sodium pyruvate, non-essential amino acids, 2 -mercaptoethanol $\left(5 \times 10^{-2} \mathrm{mM}\right)$, streptomycin/penicillin, $10 \%$ heat-inactivated fetal calf serum, and rhIL-2 $(0.04 \mathrm{ng} / \mathrm{ml})$ were added to round-bottomed wells in the 96-well plates. Virus at $1.5 \times 10^{8} \mathrm{PFU} / \mathrm{ml}$ was inactivated by UV as described above. One tenth of $1 \mathrm{ml}$ of inactivated virus was added to each well. The culture plate was left in $37^{\circ} \mathrm{C}$ incubator for $48 \mathrm{hr}$ before culture supernatants were harvested for determination of IFN- $\gamma$ concentration by ELISA assay. Coating and blocking antibody set for IFN- $\gamma$ was purchased from eBioscience. The avidin-horseradish peroxidase and TMB substrate were used for color development. Known concentrations of recombinant murine IFN- $\gamma$ were used as standards.

\section{Intracytoplasmic IFN- $\gamma$ Staining}

Single cell suspension was prepared from freshly harvested spleens at different time points after infection. Spleen cells at $5 \times 10^{5}$ cells were suspended in $100 \mu \mathrm{l}$ of RPMI 1640 medium containing rhIL-2 $(0.04 \mathrm{ng} /$ $\mathrm{ml}$ ). Cells were added to flat-bottomed 96-well plates that were coated with $100 \mu \mathrm{l}$ of anti-CD28 antibody $10 \mu \mathrm{g} /$ $\mathrm{ml}$ (clone 37.51, BD PharMingen). Dengue virus of $1.5 \times 10^{7} \mathrm{PFU}$ was added to the wells. Six hours before harvest, monesin ( $2 \mu \mathrm{M}$, Sigma-Aldrich) was added to the culture. Cells were stained with allophycocyanin (APC)-conjugated anti-CD4 or anti-CD8 antibody, and FITC-conjugated 1B11 antibody at $1 \mu \mathrm{g} / \mathrm{ml}$ final concentration for $30 \mathrm{~min}$. Cells were then washed, fixed, 
and permabilized by Cytofix (4\% paraformaldehyde in $\mathrm{dPBS}$ ) for $20 \mathrm{~min}$. After two washes, PE-conjugated antiIFN- $\gamma$ antibody in the Perm/Wash buffer was added for $30 \mathrm{~min}$. After incubation on ice, cell were washed and fixed in FACS staining buffer $/ 2 \%$ paraformaldehyde. FACSCalibur flow cytometer was used for cell acquisition. Data were analyzed by CellQuest.

\section{Immunohistochemical Staining}

Liver tissues removed from control as well as dengue virus-infected mice were embedded in O.C.T. in dry ice bath. Frozen tissues were then cryosectioned (Shandon, CRYOTOME ${ }^{\circledR}$ SME, Pittsburgh, PA) at $5 \mu \mathrm{m}$ thickness, fixed in acetone for $5 \mathrm{~min}$ and air-dried. The sections were washed with PBS and blocked in medium containing 5\% goat serum for 20 min. Rat anti mouse-CD4 (clone GK 1.5 at 1:100 dilution) or anti-CD8 (clone 536.7, at 1:100 dilution) antibody was added to the sections and left in wet chamber at $4^{\circ} \mathrm{C}$ overnight. Sections were washed twice in PBS before peroxidase-conjugated goat anti-rat IgG antibody (Jackson ImmunoResearch Laboratories, Inc., West Grove, PA) was added. After $5 \mathrm{hr}$ incubation at $37^{\circ} \mathrm{C}$, the sections were washed and DAB substrate (Vector Lab., Burlingam, CA) was applied. One to three minute(s) was allowed for color development. Hematoxylin was used as a counterstain.

\section{H \& E Staining}

Liver tissues were fixed in $4 \%$ neutral formalin solution for at least $24 \mathrm{hr}$ and then embedded in paraffin. The tissues were sectioned at $3 \mu \mathrm{m}$ in thickness. After deparaffinization and rehydration, the sections were stained in hematoxylin for $15 \mathrm{~min}$, washed, and stained in eosin for $3 \mathrm{~min}$. The sections were then dehydrated before mounting.

\section{Isolation and Identification of Lymphocytes in the Liver}

Liver tissues were collected from mice with one or two inoculations of virus or from mice receiving intravenously injection of Con A (20 mg/kg, Sigma-Aldrich). The tissues were pressed between two ground glass slides. Cell debris was removed by passing the suspension through the cotton column packed in Pasteur pipette. The single cell suspension was centrifuged and resuspended in HBSS. The cell suspension in $4 \mathrm{ml}$ was overlaid on $3 \mathrm{ml}$ of Ficoll-Pague (Amersham Pharmacia Biotech, Uppsala, Sweden). After centrifugation at $400 \mathrm{~g}$ at room temperature for $30 \mathrm{~min}$, the cells at the interface were collected and washed. Cells were spun down at $4{ }^{\circ} \mathrm{C}$, and washed two times in staining buffer. The cells were stained by PE-conjugated anti-CD4 or anti-CD8 and FITC-conjugated anti-CD44 antibodies at a final concentration of $1 \mu \mathrm{g} / \mathrm{ml}$.

\section{Determination of Liver Enzyme Levels}

Mouse blood was collected from the orbital vein. Serum obtained from clotted blood was frozen at $-70^{\circ} \mathrm{C}$ before assay. ALT and AST levels were determined in separate vials by a colometrical method. Coenzyme pyridoxal-5-phosphate was added to facilitate the determination of ALT activity. ALT catalyzes and produces pyruvate and glutamate. The pyruvate produced is then reduced to lactate by lactate dehydrogenas (LD) with the concomitant oxidation of $\mathrm{NADH}$ to $\mathrm{NAD}^{+}$. The rate of $\mathrm{NADH}$ oxidation is proportional to the ALT activity of the sample. AST catalyzes and produces oxaloacetate and is reduced to malate dehydrogenease $(\mathrm{MDH})$ with the concomitant oxidation of $\mathrm{NADH}$ to $\mathrm{NAD}^{+}$. Likewise, the rate of $\mathrm{NADH}$ oxidation is proportional to the AST activity of the sample. NADH oxidation was measured at $340 \mathrm{~nm}$ and read by automated Abbott Alcyon 300i (Abbott Park, IL).

\section{Detection and Isotyping Dengue Virus Specific Antibodies}

Mice were bled from the orbital vein. Sera were collected after the clotted blood was centrifuged. Sera were kept in $-70^{\circ} \mathrm{C}$ before assay. EIA plates (Nalge Nunc, Dermark) were used for antibody detection. Dengue virus at $5 \times 10^{7} \mathrm{PFU} / \mathrm{ml}$ was sonicated for total of $15 \mathrm{~min}$ on ice and diluted tenfold in coating buffer. Supernatants from uninfected C6/36 culture were diluted tenfold and used as mock control. The wells were coated with $50 \mu \mathrm{l}$ of the virus preparation and the mock supernatant overnight at $4{ }^{\circ} \mathrm{C}$. The wells were then washed with PBS/0.5\% Tween-20 for three times and blocked with blocking buffer at $4{ }^{\circ} \mathrm{C}$ overnight and then washed. Duplicate samples of sera and control supernatants were diluted 1:200 before addition to wells. The plates were left at room temperature for $1 \mathrm{hr}$. After washing, detection antibody biotin-conjugated goat anti-mouse IgG in 1:5,000 or biotin-conjugated goat anti-mouse IgM in 1:5,000 was added. The plates were again left at room temperature for $1 \mathrm{hr}$ before wash with buffer. After the addition of avidin-conjugated horseradish peroxidase $(1: 250)$ the plates were left at room temperature for $30 \mathrm{~min}$. The wells were then washed five times with buffer and let stand for 1-2 min before addition of TMB substrate (eBioscience). The plates were left at room temperature and protected from light for $15 \mathrm{~min}$. The color development was stopped by $2 \mathrm{~N}$ $\mathrm{H}_{2} \mathrm{SO}_{4}$. The absorbance was read at $450 \mathrm{~nm}$.

\section{In Situ Detection of DNA Fragmentation}

Liver tissues were fixed in $4 \%$ paraformadehyde. Fixed sections were treated with $0.1 \%$ Triton ${ }^{\mathbb{R}} \mathrm{X}-100$ in $0.1 \%$ sodium citrate for 2 min on ice. The sections were then blocked with $0.1 \mathrm{M}$ Tris- $\mathrm{HCl}(\mathrm{pH}$ 7.5) containing $20 \%$ FCS. DNA fragmentation was detected on sections by using the In Situ Cell Death Detection Kit AP (Boehringer Mannheim, Mannheim, Germany). The staining was performed according to manufacturer's instructions. In brief, TUNEL reaction mixture (TdTmediated dUTP nick end labeling) at enzyme solution to label solution 1:9 was added. Converter-POD (peroxidase-conjugated anti-fluorescein antibody) as added 
after wash. DAB was used as substrate for color development and methyl green as a counterstain.

\section{RESULTS}

\section{Dengue Virus Disseminates in Immunocompetent Mice}

C57BL/6 mice were inoculated intravenously with $10^{8}$ PFU of dengue virus serotype-2, strain 16681. RT-PCR results showed that dengue viral RNA was detectable in mouse spleen, liver, brain, and serum at days 1, 3, 5, and 7 after infection (Fig. 1A,B), demonstrating that dengue virus was disseminated in the mouse. Real-time RTPCR revealed that viral RNA peaked at day 3 when there was $2.7 \times 10^{6}-3.6 \times 10^{6}$ copies of viral RNA per ml of serum in the mouse. The level fell to $5.1 \times 10^{4}$ $4.6 \times 10^{5}$ copies per ml of serum at day 5 . Together, these results show that dengue virus serotype-2 strain 16681 inoculated intravenously established viremia and disseminated to various tissues in immunocompetent mice.

\section{T Cells Are Activated After Dengue Virus Infection}

The expression of CD69 is commonly used as a marker to assess early lymphocyte activation [Testi et al., 1989]. In the course of dengue virus infection, the numbers of $\mathrm{CD}^{+}$and $\mathrm{CD}^{+} \mathrm{T}$ cells expressing CD69 at days 3,5 , and 7 after infection were significantly higher than the control mice (Table I). During this time, the number of T cells in infected mice that expressed CD69 was 2.0-3.5 times of that in the control mice. These data show that dengue virus infection induced $\mathrm{T}$ cell activation.

To understand further the kinetics of $\mathrm{T}$ cell activation and function, another activation marker was studied. It has been reported in the LCMV model that increased expression of $O$-glycosylated $\mathrm{CD} 43$, as recognized by 1B11 monoclonal antibody, on $\mathrm{CD} 8^{+} \mathrm{T}$ cells, correlates with their effector function [Harrigton et al., 2000]. The expression of $\mathrm{O}$-glycan by $\mathrm{CD} 4^{+} \mathrm{T}$ cells and its correlation with activation state has also been reported in mice after infection with Moloney murine sarcoma and leukemia virus complex (MoMSV) [Schepers et al., 2002]. Therefore, 1B11 monoclonal antibody was used to identify and enumerate activated and functional $\mathrm{T}$ cells. Data in Figure 2 show that at day 3 of infection, the numbers of $\mathrm{CD}^{+}$and $\mathrm{CD}^{+} \mathrm{T}$ cells expressing $O$ glycosylated CD43 in dengue virus-infected mice became significantly higher than the control mice. The mean numbers of O-glycan-expressing $\mathrm{CD} 8^{+}$and $\mathrm{CD} 4^{+} \mathrm{T}$ cells peaked at day 5 of infection and declined thereafter. At the peak, they were 7.0- and 1.2-fold, respectively, higher than the control mice. In contrast, $O$-glycosylated CD43 T cells in mice inoculated with mock or UV-inactivated virus were not significantly different from control mice. The results suggest that $\mathrm{T}$ cells were functionally activated after dengue virus infection.

A
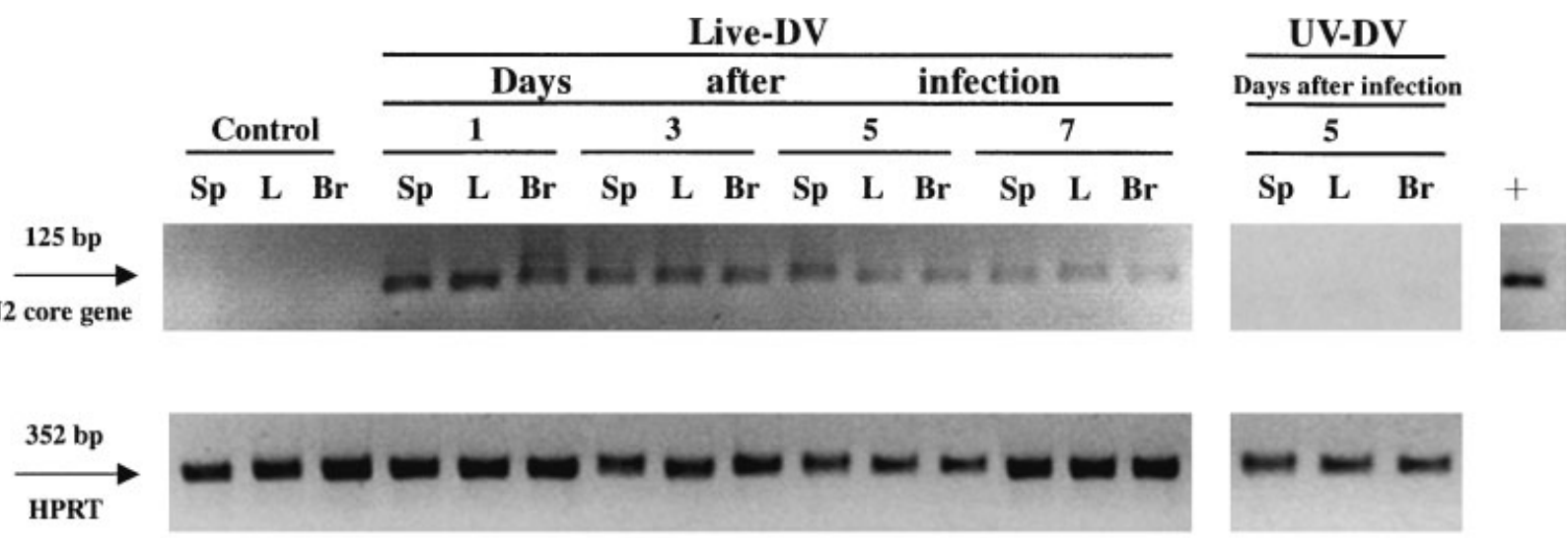

B

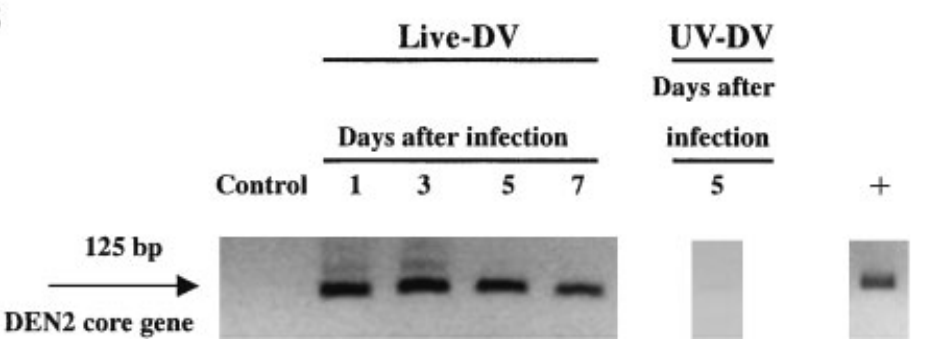

Fig. 1. Dengue virus disseminated in immunocompetent mice. (A) Viral core genes were detected by RTPCR in the spleen (Sp), liver (L), brain (Br), and (B) serum at different time points after infection. RT-PCR product of viral core gene is $125 \mathrm{bp}$. Control mice were injected with PBS. +, Culture supernatant from dengue virus-infected C6/36 cells; Live-DV, tissues or serum RNA from mice inoculated with live dengue virus mice; UV-DV, tissues or serum RNA from mice inoculated with UV-inactivated dengue virus; HPRT, house-keeping gene. The molecular size for HPRT is $352 \mathrm{bp}$. 
TABLE I. T Cells Express CD69 After Infection

\begin{tabular}{lcccc}
\hline & \multicolumn{4}{c}{ Cell number $\left(\times 10^{6}\right)$} \\
\cline { 2 - 5 } & & \multicolumn{3}{c}{ Days after infection } \\
\cline { 2 - 5 } Cell type $^{\mathrm{a}}$ & Control & 3 & 5 & 7 \\
\hline CD8 $^{+}$T cells & $0.4 \pm 0.1$ & $1.4 \pm 0.3^{* *}(3.5)^{\mathrm{b}}$ & $1.1 \pm 0.8^{* *}(2.8)$ & $1.0 \pm 0.4^{* *}(2.5)$ \\
CD4 $^{+}$T cells & $0.8 \pm 0.4$ & $2.7 \pm 0.7^{* *}(3.4)$ & $2.8 \pm 1.7^{* *}(3.4)$ & $1.6 \pm 0.9^{*}(2.0)$ \\
\hline
\end{tabular}

${ }^{\text {a }}$ Spleen cells were collected from control mice and mice infected with dengue virus serotype-2 virus at days 3,5 , and 7 after infection. The number of lymphocytes expressing CD69 $\left(\times 10^{6}\right)$ was calculated from the total number of $\mathrm{CD}^{+}$or $\mathrm{CD} 8^{+} \mathrm{T}$ cells and the percent of cells expressing CD69. Six to nine mice were included for each time point.

${ }^{\mathrm{b}}$ The mean number of cells expressing CD69 in infected mice divided by that in control mice.

$* P<0.05$, comparing the number of $\mathrm{CD} 9^{+}$cells in infected mice with that in uninfected mice.

$* * P<0.005$, comparing the number of $\mathrm{CD}^{*} 9^{+}$cells in infected mice with that in uninfected mice.

\section{Activated T Cells Produce IFN- $\gamma$}

To investigate the effector function of activated $\mathrm{T}$ cells, spleen cells collected at different time points of infection were cultured and the supernatants were assayed for IFN- $\gamma$. Not only spleen cells from infected mice produced IFN- $\gamma$ (Fig. 3) but the kinetics of IFN- $\gamma$ production also followed that of T cell activation (Fig. 2). IFN- $\gamma$ production $(19.3 \pm 6.9 \mathrm{ng} / \mathrm{ml})$ peaked at day 5 of infection, when $18.3 \%$ of splenic $\mathrm{CD} 8{ }^{+} \mathrm{T}$ cells and $4.6 \%$ of $\mathrm{CD}^{+} \mathrm{T}$ cells were IFN- $\gamma$ producers (Fig. 4A). In contrast, spleen cells from mice inoculated with UVinactivated dengue virus and those with mock supernatants produced $<1 / 10$ levels of IFN- $\gamma$ at 5 days after inoculation (Fig. 3). Interestingly, of the total IFN- $\gamma$ producing cells, about $76 \%$ were $\mathrm{CD}^{+} \mathrm{T}$ cells and $24 \%$ $\mathrm{CD}^{+} \mathrm{T}$ cells, demonstrating that the majority of functionally active cells were $\mathrm{CD} 8^{+} \mathrm{T}$ cells. Phenotyping showed $82.8 \%$ of $\mathrm{CD}^{+}$-IFN- $\gamma^{+} \mathrm{T}$ cells and $61.6 \%$ of $\mathrm{CD} 4^{+}$-IFN- $\gamma^{+}$T cells expressed $O$-glycosylated CD43 and $>97 \%$ of all IFN- $\gamma^{+}$T cells were CD $44^{\text {hi }}$ (Fig. 4B). These results demonstrate that most activated $\mathrm{CD} 8^{+}$ $\mathrm{T}$ cells expressing $\mathrm{O}$-glygan and $\mathrm{CD} 44^{\mathrm{hi}}$ were functionally active in mice infected by dengue virus.

\section{Hepatic Infiltration in Mice Infected With Dengue Virus}

In examining liver sections, cellular infiltration was observed in mice at day 5 after infection (Fig. 5B). H \& E stain revealed that the infiltrating cells were mostly lymphoid cells. Immunohistochemical staining revealed that the infiltrating cells constituted of both $\mathrm{CD}^{+}$ and $\mathrm{CD} 4^{+} \mathrm{T}$ cells (Fig. 6B,E). The distribution of $\mathrm{CD} 4^{+}$ and $\mathrm{CD} 8^{+} \mathrm{T}$ cells followed different patterns. While most of the $\mathrm{CD} 4^{+} \mathrm{T}$ cells clustered around the portal vein with some scattered in the parenchyma, most of $\mathrm{CD} 8^{+} \mathrm{T}$ cells were scattered in the hepatic acinus (personal observation). Flow cytometric analysis of hepatic infiltrating $\mathrm{T}$ cells showed that of total infiltrating $\mathrm{T}$ cells isolated, about $62.5 \%$ were $\mathrm{CD} 8^{+} \mathrm{T}$ cells and $37.5 \% \mathrm{CD} 4^{+} \mathrm{T}$ cells (Fig. 7B), contrast to acute hepatitis induced by Con A where the majority of infiltrating cells were $\mathrm{CD} 4^{+} \mathrm{T}$ cells (71.7\%) (Fig. 7A). Moreover, $69.9 \%$ of infiltrating $\mathrm{CD}^{+}$ T cells were of CD $44^{\text {hi }}$ phenotype (Fig. 7D). These results are consistent with the observation in Figure 4A that most of the functionally active $\mathrm{T}$ cells in the spleen were $\mathrm{CD}^{+} \mathrm{T}$ cells.

\section{Liver Injury}

Serum ALT and AST levels were then assayed to determine whether $\mathrm{T}$ cell infiltration was associated with liver damage. The results in Table II show that liver enzyme levels in dengue virus-infected mice were significantly higher than control mice (days 3 and 5 for ALT and days 3, 5, 7 for AST), although UV-inactivated dengue virus also induced a transient elevation of ALT and AST at day 3 after inoculation. In situ detection of DNA fragmentation by TUNEL assay shows that liver cells are apoptotic (Fig. 8), similar to what is reported in infected humans [Couvelard et al., 1999]. Interestingly, the kinetics and peak of liver enzyme levels correlated with that of activated T cells (Fig. 2) suggesting that activated $\mathrm{T}$ cells were associated with liver damage. Moreover, the liver enzyme levels also correlated with the peak of IFN- $\gamma$ production (Fig. 3). The degree of cellular infiltration also positively correlated with the level of IFN- $\gamma$ produced (Table III).

\section{Second Inoculation of Dengue Virus Induces Greater Liver Damage}

In a separate experiment, mice were given a second inoculum of dengue virus at the time when activated T cell numbers and specific IgM levels declined and before specific IgG rose. The AST levels in these mice increased rapidly. At the third day after second inoculation, AST levels were 1.7 times that of mice given a single dose of the virus. Interestingly, a second virus inoculation resulted in more pronounced cellular infiltration (Figs. $5 \mathrm{C}$ and $6 \mathrm{C}, \mathrm{F}$ ). The infiltrating $\mathrm{CD} 8^{+} / \mathrm{CD}^{+} \mathrm{T}$ cell ratio was greater in mice receiving a second dose of virus (5.8/1) than in those given one inoculation $(3 / 2)$ (Fig. 7B,C). Moreover, although in mice receiving only one dengue virus inoculation only $69.9 \%$ of $\mathrm{CD}^{+} \mathrm{T}$ cells expressed CD $44^{\mathrm{hi}}$ phenotype, $>95 \%$ of infiltrating $\mathrm{CD}^{+}$ T cells in mice receiving second dengue virus inoculation expressed CD44 ${ }^{\mathrm{hi}}$ phenotype (Fig. 7E), illustrating further the association of activated $\mathrm{CD} 8^{+} \mathrm{T}$ cells and liver injury in dengue. 
A
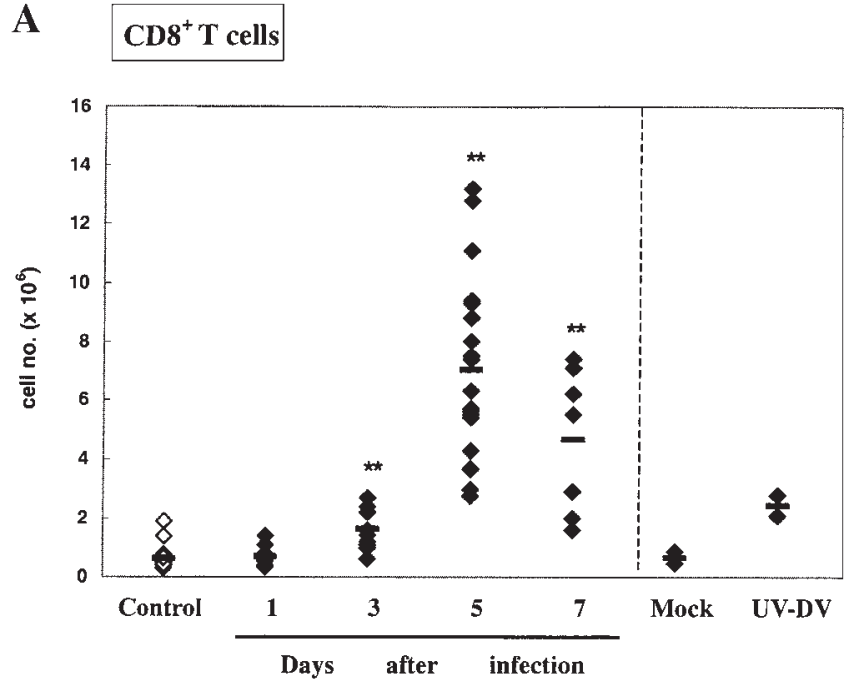

B
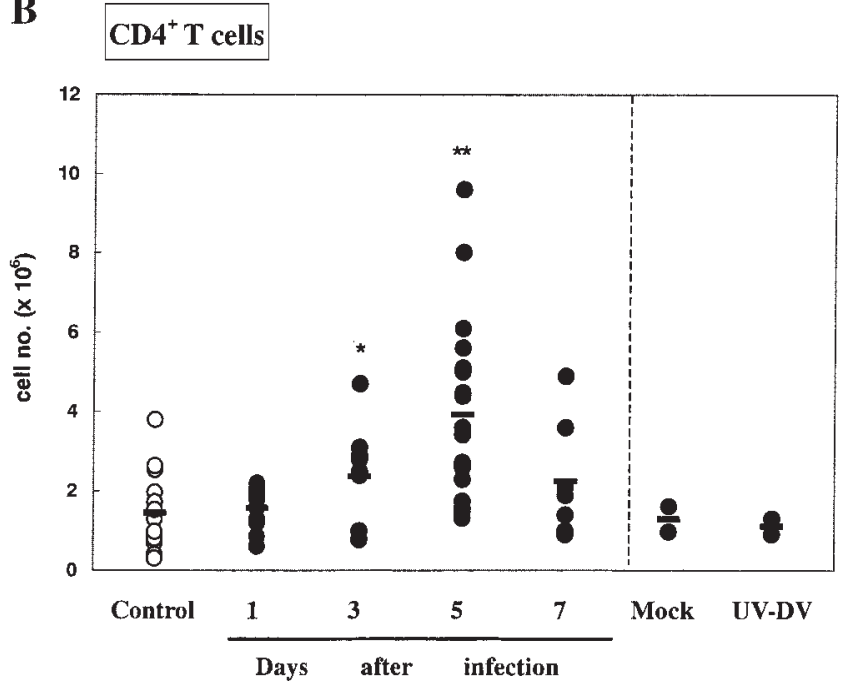

Fig. 2. T cell expression of $O$-glycosylated CD43 peaks at day 5 after dengue virus infection. Splenocytes were harvested from dengue virusinfected mice at days 1, 3, 5, and 7 after infection. Spleen cells from mice receiving PBC (control), C6/36 culture supernatant (mock), and UVinactivated dengue virus (UV-DV) were harvested at day 5 after inoculation. Cells were stained with PE-conjugated anti-CD8 or PEconjugated anti-CD4 and FITC-conjugated 1B11 antibodies. The number of $\mathrm{CD}^{+}(\mathbf{A})$ and $\mathrm{CD}^{+}(\mathbf{B}) \mathrm{T}$ cells expressing O-glycan in the course of infection was calculated from the total number of $\mathrm{T}$ cells and the percentage of cells stained positive by 1B11 monoclonal antibody. Each symbol represents one mouse. The horizontal lines indicate the mean value. $* * *$ indicate $P<0.05$ and $P<0.005$, respectively, comparing the mean number of cells from infected mice at each time point after infection with that from control mice without infection.

\section{DISCUSSION}

Both immune enhancement and viral virulence hypotheses recognize the importance of achieving high viral titer in the cause of severe dengue disease [Halstead, 1970, 1980, 1988; Rosen, 1977a; Gubler et al., 1978; Gubler, 1988]. The antibody enhancement hypothesis attempts to explain the observation of individuals experiencing secondary infection with a heterologous dengue serotype had a significantly higher

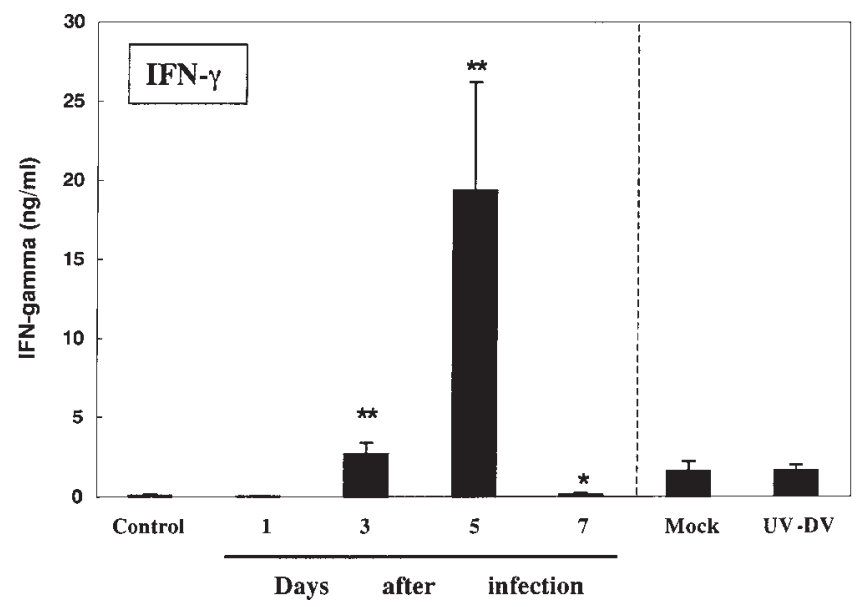

Fig. 3. IFN- $\gamma$ production peaks at day 5 of infection. Spleen cells were harvested from same groups of mice at the same time points as described in legend of Figure 2. Virus were UV-inactivated and added to the wells containing $5 \times 10^{5}$ spleen cells. Culture supernatants were collected after $48 \mathrm{hr}$ of incubation. IFN- $\gamma$ concentration in the supernatants was determined by ELISA. Six to ten mice were used at each time point. ${ }^{*}$, ** indicate $P<0.05$ and $P<0.005$, respectively. The $P$ value was calculated from comparing the IFN- $\gamma$ concentration in the spleen cell culture supernatants from mock supernatant, UV-inactivated virus, or live virus infected mice with that in supernatants from uninfected control mice.

risk of developing dengue hemorrhagic fever/dengue shock syndrome [Halstead, 1970, 1980, 1988; Sangkawibha et al., 1984; Burke et al., 1988; Kliks et al., 1989]. It was shown in vitro that in the presence of low titers of heterologous antibody, dengue virus replicates to higher titers in human monocytes [Kliks et al., 1989]. This hypothesis emphasizes the importance of heterologous antibody in enhancing the replication of the second virus in antigen-presenting cells. The enhancement results in profound activation of preexisting cross-reactive cytotoxic $\mathrm{T}$ cells and release of cytokines and cellular mediators, thus leading to subsequent immunopathological processes and dengue hemorrhagic fever/dengue shock syndrome [Innis, 1995; Gubler, 1998; Rothman and Ennis, 1999]. However, the link between T cell activation and pathology has never been established. The viral virulence hypothesis was based on the observation that some dengue viruses have greater epidemic potential than others [Rosen, 1977b; Gubler et al., 1978]. These 'virulent' virus strains have the advantage to replicate faster and to higher levels, and as a result cause higher levels of viremia. To study immunopathogenesis of dengue in immunocompetent mice, virus virulence and titer were taken into considerations. We established successfully this mouse model by intravenous injection of high titers of the hemorrhagic strain dengue virus serotype-2 16681 [Russell et al., 1967]. The infected mice became viremic and the virus disseminated. Moreover, the infection induced $\mathrm{T}$ cell activation.

Immunocompetent mice have not been used widely to study $\mathrm{T}$ cell responses to dengue virus. $\mathrm{A} / \mathrm{J}$ mice inoculated intravenousely with dengue virus developed transient thrombocytopenia and produced anti-platelet 
A
Control

0.09

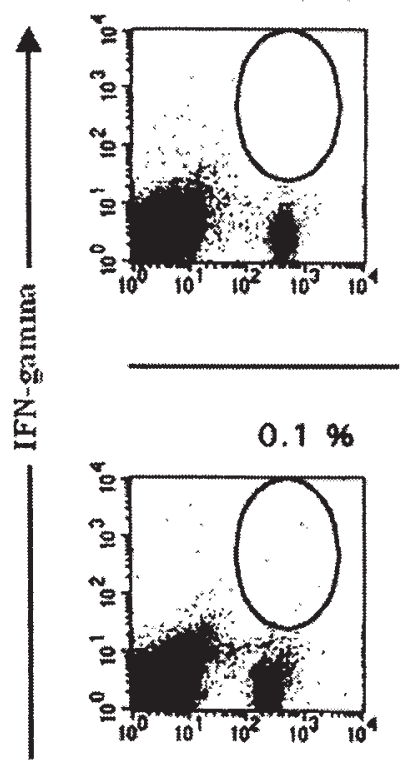

Infected

$18.3 \%$

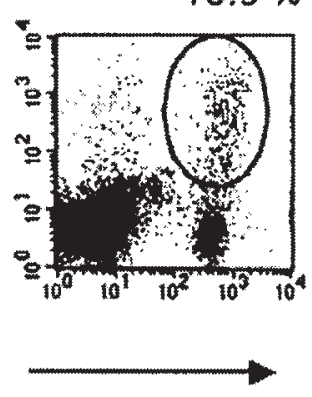

cDs

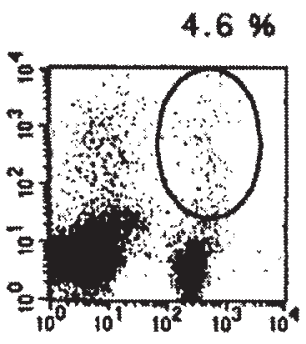

$\mathrm{CD} 4$

Fig. 4. CD4 ${ }^{+}$as well as $\mathrm{CD} 8^{+} \mathrm{T}$ cells produce IFN- $\gamma$. Spleen cells were harvested from mice at day 5 of infection and cultured in wells containing plate-bound anti-CD28 antibody, rIL-2, and DV $\left(3 \times 10^{7} \mathrm{PFU} / 100 \mu \mathrm{l}\right)$. Cells were stained with APC-conjugated antiCD8 or anti-CD4, PE-conjugated anti-IFN- $\gamma$, and FITC-conjugated 1B11 or anti-CD44 antibodies. (A) $\mathrm{CD}^{+}$and $\mathrm{CD} 4^{+} \mathrm{T}$ cells produce IFN$\gamma$. The numbers above the dot plot indicate percent $\mathrm{CD} 8^{+} \mathrm{IFN} \gamma$-positive

antibody after primary infection and upon challenge [Huang et al., 2000]. However, mouse T cell responses, cytokine production and immunopathology to dengue virus were not reported. So far as we know, we are the first to report that in dengue virus infected mice, T cells especially $\mathrm{CD} 8^{+} \mathrm{T}$ cells are activated and constitute the major cell population that infiltrate the liver. The $\mathrm{T}$ cell infiltration also seems to associate with liver injury.

The association of $\mathrm{T}$ cell activation, especially that of $\mathrm{CD}^{+} \mathrm{T}$ cells, with more severe clinical syndrome has been shown in several dengue clinical studies. As mentioned above, patients with dengue hemorrhagic fever had higher serum sCD8 compared to that with dengue fever [Kurane et al., 1991]. The percentages of CD8 ${ }^{+}$ $\mathrm{T}$ cells and NK cells expressing CD69 are higher within $72 \mathrm{hr}$ of fever onset in pediatric patients who later developed dengue hemorrhagic fever than in those developed dengue fever, including patients with primary and secondary infections with dengue virus serotype-1, 2, and 3 [Green et al., 1999]. Examining a dengue outbreak in Southern Taiwan, Lei et al. [2001] also reported that CD69 expression is high on T cells and the expression is higher on $\mathrm{CD} 8^{+} \mathrm{T}$ cells than on $\mathrm{CD} 4^{+}$ $\mathrm{T}$ cells. These data indicate that early CD69 expression, especially on $\mathrm{CD} 8^{+} \mathrm{T}$ cells, correlates with severe outcome of dengue virus infection.
B CDS T cells
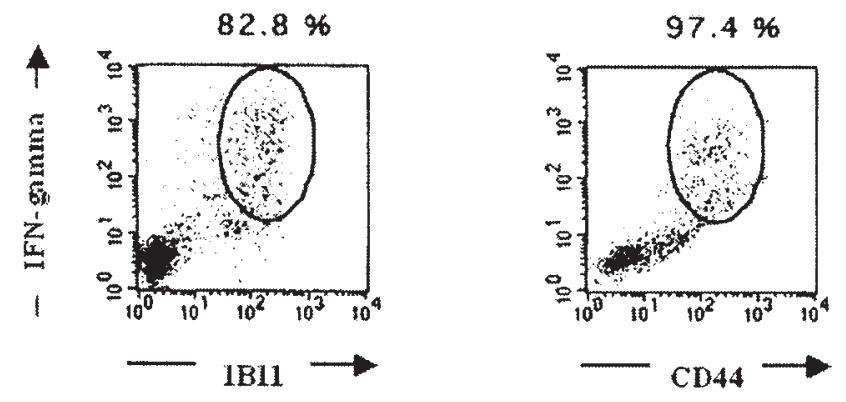

\section{CD4 T cells}
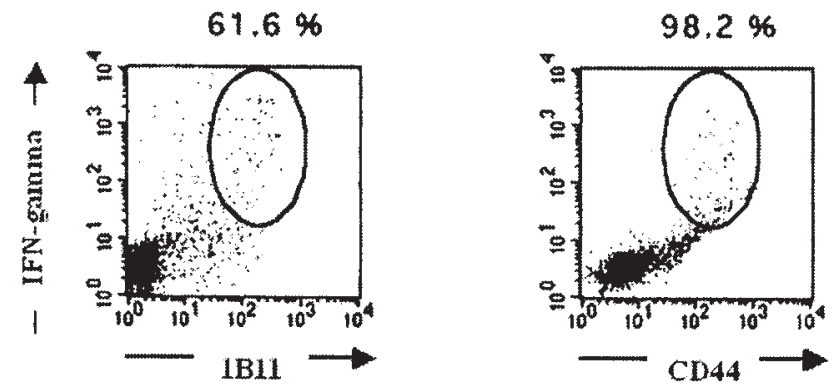

or $\mathrm{CD}^{+}$IFN $\gamma$-positive cells in $\mathrm{CD}^{+}$or $\mathrm{CD} 4^{+} \mathrm{T}$ cell populations. (B) Phenotyping IFN $\gamma$-positive cells. The percentages of IFN- $\gamma$ producing $\mathrm{CD}^{+}$and $\mathrm{CD} 4^{+} \mathrm{T}$ cells expressing $O$-glycosylated $\mathrm{CD} 43$ or $\mathrm{CD} 44^{\mathrm{hi}}$ are indicated. Forty thousand cells were acquired and analyzed by CellQuest. Three mice were included in each experiment and the experiment was repeated three times. Data from one representative mouse are shown.

It has also been reported that the $\mathrm{CD} 8^{+} \mathrm{T}$ cells derived from dengue immune donors have functional activity. The $\mathrm{CD}^{+} \mathrm{T}$ cell clones derived from dengue immune donors recognizing epitopes on NS3 (non-structural protein 3) are cytotoxic [Livingston et al., 1995]. The Flavivirus cross-reactive $\mathrm{T}$ cells isolated from mice infected with Murray Valley encephalitis (MVE) virus not only have cytotoxic activity but also produce IFN- $\gamma$ [Regner et al., 2001]. The present study in mice infected with high titers of dengue virus serotype-2 strain 16681 showed that the numbers of $\mathrm{CD}^{+}$as well as $\mathrm{CD} 4^{+} \mathrm{T}$ cells expressing CD69 are up early in the course of infection (Table I). The activated $\mathrm{T}$ cells are functionally active as demonstrated by their ability to produce IFN- $\gamma$ (Fig. 4). Moreover, this study comparing the responses induced by UV-inactivated virus and that by infection with live virus showed that $T$ cell responses are results of a true infection. These results demonstrated that $\mathrm{CD} 8^{+}$ $\mathrm{T}$ cell responses in C57BL/6 mice injected with high titers of hemorrhagic strain of dengue virus serotype-2 model the $\mathrm{CD}^{+} \mathrm{T}$ cell responses in human disease. Thus, this animal model is useful for the study of the role of activated $T$ cells in the pathogenesis of dengue.

The liver is not thought to be a major target organ of dengue infection, but the involvement of liver cells in pathogenesis of dengue virus infection has been indi- 

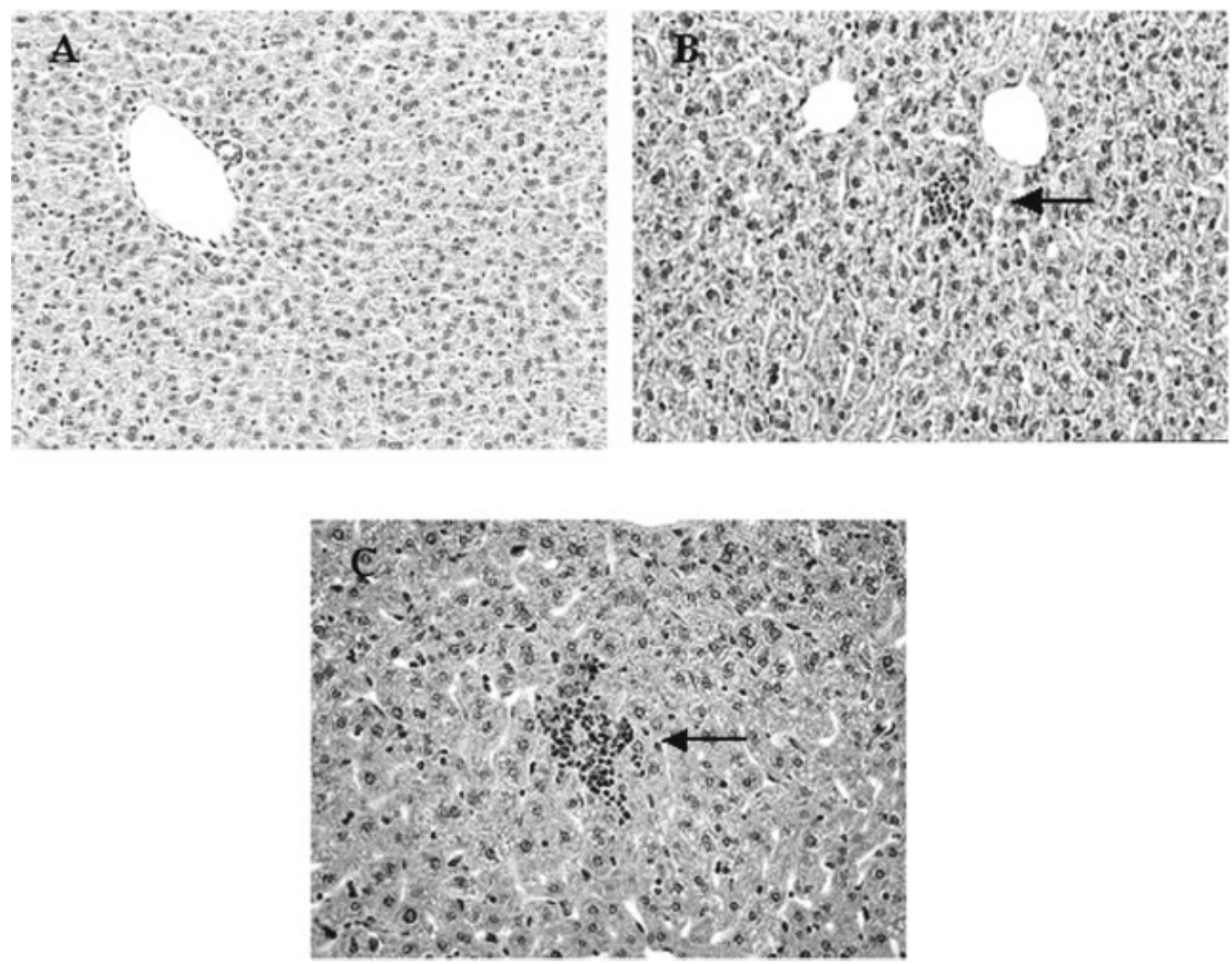

Fig. 5. Dengue virus infection results in hepatic cellular infiltration. Liver tissues were removed from control mouse (A), mouse at 5 days after receiving one inoculation of virus $(\mathbf{B})$ and mouse at 3 days after receiving a second inoculation of virus $(\mathbf{C})$. Tissues were fixed in $10 \%$ buffered formaldehyde and stained with hematoxylin and eosin. The magnification was $200 \times$.

cated by clinical signs of hepatomegaly, abnormal liver function, pathological findings, and detection of viral antigen [Bhamarapravati et al., 1967; Rosen et al., 1989; Hall et al., 1991; Lanciotti et al., 1992; Kangwanpong et al., 1995; Couvelard et al., 1999; Huerre et al., 2001]. In examining fatal dengue hemorrhagic fever cases, liver is the tissue most often the virus is isolated [Rosen et al., 1989; Innis, 1995; Bhamarapravati, 1997; Huerre et al., 2001]. Dengue patients were reported to have elevated AST levels and AST elevation is associated with hemorrhage [Kalayanarooj et al., 1997; Monath et al., 2000]. In dengue virus induced hepatitis, the level of AST is higher than ALT with a ratio of around 11.5 while other types of virally induced hepatitis have higher ALT levels than AST [Kuo et al., 1992; Nguyen et al., 1997; Lei et al., 2001]. Serum liver enzyme AST level is higher in dengue hemorrhagic fever patients than in dengue fever patients [Kalayanarooj et al., 1997; Monath et al., 2000; Wahid et al., 2000]. It has also been reported that dengue virus induces HepG2 apoptosis and production of RANTES [Lin et al., 2000a,b]. Together, these reports indicate that dengue virus infection can cause liver pathology. The mechanism of liver damage has never been examined.

Examining liver pathology of 100 fatal pediatric (age 5 months to 14 years) dengue hemorrhagic fever cases, Bhamarapravati et al. [1967] reported that cellular infiltration was noted in 64 cases. Megakaryocytes, lymphocytoid cells, and rarely neutrophils were observed in sinusoids. Cellular infiltration in the portal areas was composed of young lymphocytes, plasmacytoid cells and some histiocytes [Bhamarapravati et al., 1967]. A recent liver histopathological report of five fatal pediatric (age 10-72 months) cases revealed that liver histopathology was detected in four out of five postmortem examinations [Huerre et al., 2001], but little or no inflammatory response was found in four cases and moderate infiltration, mainly in the periportal area in only one case [Huerre et al., 2001]. Therefore, it appears that liver histopathology is common in patients who died of dengue hemorrhagic fever but it remains to be determined virus infecting liver cells, lymphocyte infiltration or both is the cause of liver pathology.

In this study, mice infected with dengue virus had significantly higher liver enzyme levels (days 3, 5, and 7, Table II) when the numbers of activated $\mathrm{T}$ cells were high (days 3, 5, and 7, Fig. 2). Analysis of infiltrating cells showed that they are activated lymphocytes and the majority are $\mathrm{CD}^{+} \mathrm{T}$ cells (Fig. 7B,D). In situ detection of DNA fragmentation by TUNEL assay showed that liver cells were apoptotic (Fig. 8), similar to what is reported in infected humans [Couvelard et al. 1999]. These data strongly indicate that liver injury in dengue virus infection is associated with activated 

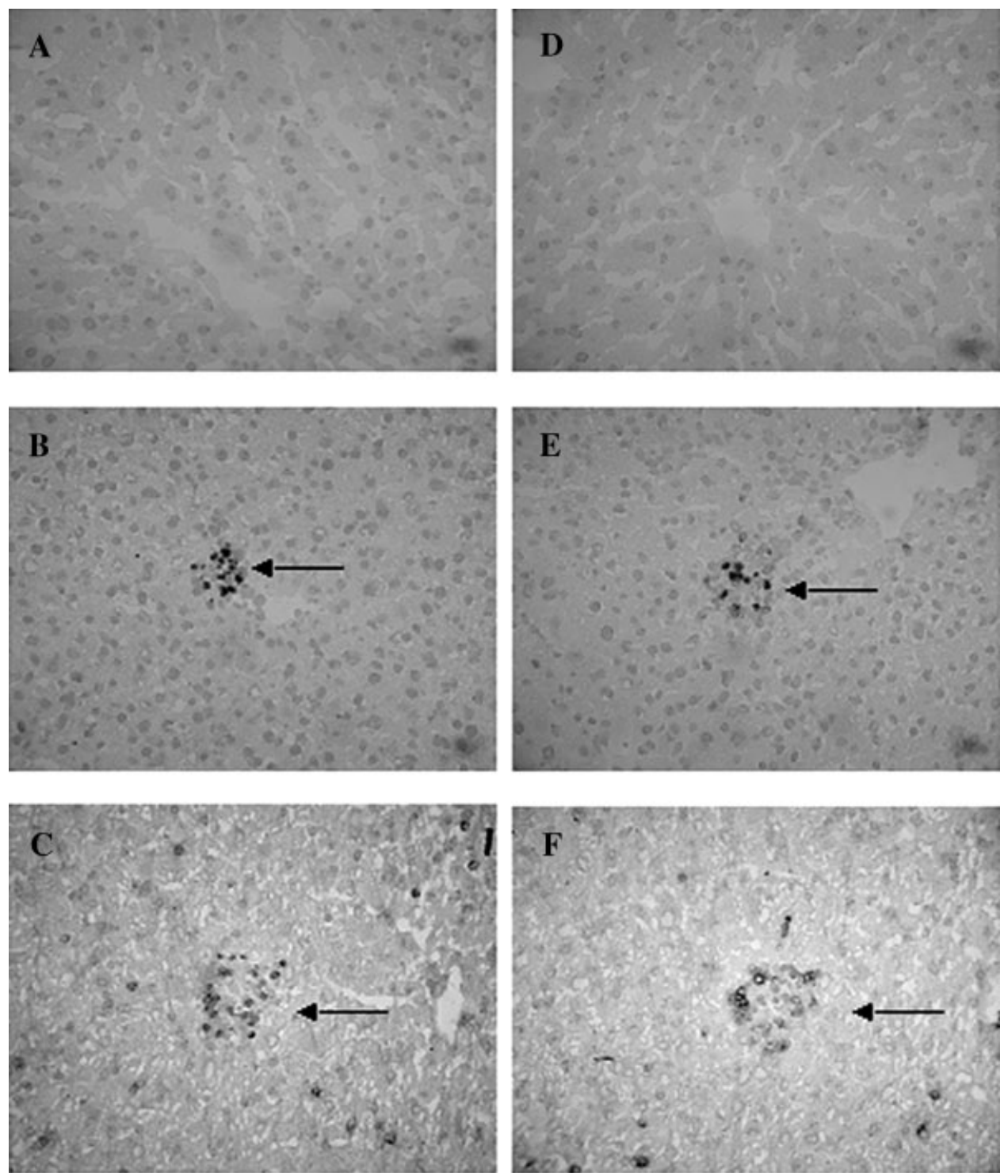

Fig. 6. The cellular infiltrates in the liver consist of $\mathrm{CD} 8^{+} \mathrm{T}$ and $\mathrm{CD} 4^{+} \mathrm{T}$ cells. Liver tissues were from control mouse $(\mathbf{A}, \mathbf{D})$, mouse at 5 days after receiving one inoculation of virus $(\mathbf{B}, \mathbf{E})$ and mouse at 3 days after receiving a second inoculation of virus $(\mathbf{C}, \mathbf{F})$. Cryosectioned tissues were stained with rat anti-mouse CD8 $(\mathbf{A}, \mathbf{B}, \mathbf{C})$ or anti-CD4 antibody $(\mathbf{D}, \mathbf{E}, \mathbf{F})$ followed by peroxidase-conjugated goat anti-rat IgG antibody. $\mathrm{DAB}$ was used as substrate for color development. Arrows point at positive cells. The magnification was $200 \times$.

lymphocyte, especially $\mathrm{CD}^{+} \mathrm{T}$ cell infiltration. However, these results do not rule out the contribution of direct viral damage to the liver.

Dengue virus infection induced specific antibody response. Specific IgM became significantly higher at day 3 and peaked at day 5 of infection while specific IgG was detectable at day 5-7 and peaked at day 14 (unpublished data). The infiltration in liver was more pronounced in mice receiving a second dose of dengue virus (Figs. 5C and 6C,F) at day 7 when T cells and specific IgM declined and before specific IgG elevated. The liver enzyme AST levels in these mice are much higher than in those receiving only one injection. The ratio of infiltrating $\mathrm{CD}^{+}$to $\mathrm{CD} 4^{+} \mathrm{T}$ cells was $3 / 2$ in mice receiving single inoculation and became 5.8/1 in mice receiving two viral inoculations (Fig. 7B,C), showing that $\mathrm{CD}^{+} \mathrm{T}$ cells greatly expanded upon second inoculation. This correlation strengthened further the association between liver injury and $\mathrm{CD}^{+} \mathrm{T}$ cell infiltration. It is worth noting that same observation was repeated in mice receiving lower dose of inoculum $\left(1.5 \times 10^{7} \mathrm{PFU}\right)$, indicating the phenomenon is not caused by high viral titer per se. Although it has not been documented that patients who later develop dengue hemorrhagic fever have been inoculated with dengue virus by multiple mosquito bites at different times within a short time frame, the chances of a person living in an endemic area being bitten by infected 
Hepatic Lymphocyte Infiltration in Dengue

A

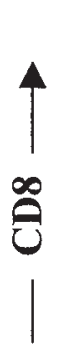

$9.5 \%$

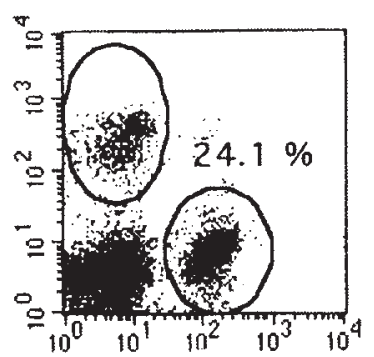

- CD4
B

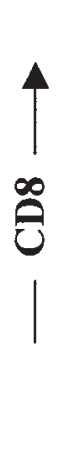

$29.6 \%$
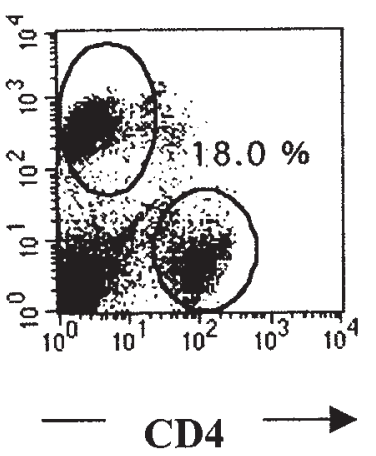

C

$47.8 \%$

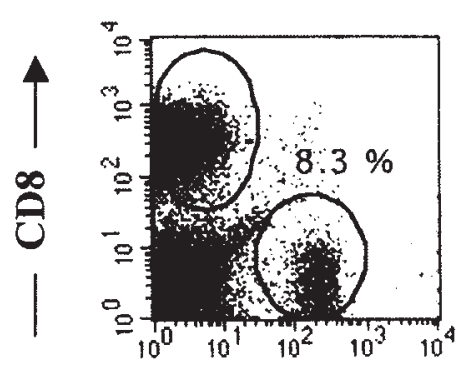

CD4
D

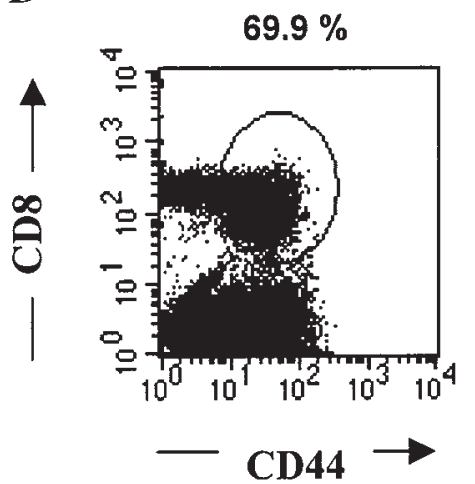

E

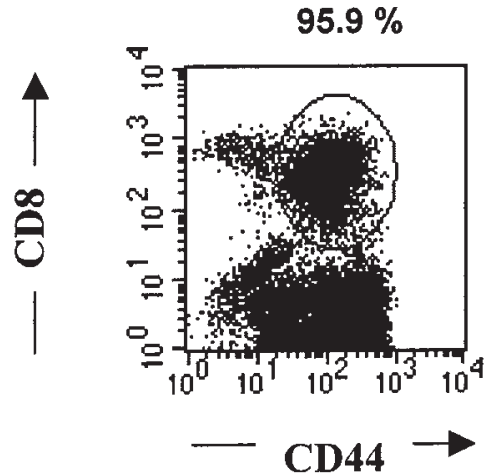

Fig. 7. Activated $\mathrm{CD}^{+} \mathrm{T}$ cells constitute the major $\mathrm{T}$ cell population infiltrating the liver in DV-infected mice. Liver tissues were removed from mouse at $16 \mathrm{hr}$ after Con A injection (A), mouse at 5 days after receiving one inoculation of virus $(\mathbf{B}, \mathbf{D})$ and mouse at 3 days after receiving a second inoculation of virus $(\mathbf{C}, \mathbf{E})$. Single cell suspension was prepared and mononuclear cells were separated on Ficoll-Paque

mosquitoes more than once are high. This model predicts that upon receiving a second dose of virus, the rapid expansion of $\mathrm{CD}^{+} \mathrm{T}$ cells can very well result in infiltration to the liver. Experiments are underway to investigate the direct causal relationship between $\mathrm{CD}^{+}$ $\mathrm{T}$ cell infiltration and liver injury. gradient. The mononuclear cells were stained with PE-conjugated antiCD8 and APC-conjugated anti-CD4 antibodies (A, B, C) or PEconjugated anti-CD8 and FITC-conjugated anti-CD44 antibodies (D, E). The numbers above the dot plots indicate the percentage of $\mathrm{CD} 4^{+}$or CD8 ${ }^{+}$T cells in the total mononuclear cells isolated $(\mathbf{A}, \mathbf{B}, \mathbf{C})$ or $\mathrm{CD}^{+} \mathrm{T}$ cells expressing CD $44^{\mathrm{hi}}$ phenotype $(\mathbf{D}, \mathbf{E})$.

Clinical studies have shown that serum IFN- $\gamma$ levels are high in dengue hemorrhagic fever patients [Kurane et al., 1989, 1991]. This present study showed that IFN- $\gamma$ levels are high at the peak of T cell activation (Fig. 3) and the extent of cellular infiltration correlates with the amounts of IFN- $\gamma$ secreted (Table III). However, it

TABLE II. Liver Enzyme Levels Increase in Mouse Sera After Infection

\begin{tabular}{|c|c|c|c|c|c|c|}
\hline \multirow[b]{2}{*}{ Liver enzyme ${ }^{a}(\mathrm{U} / \mathrm{L})$} & \multirow[b]{2}{*}{ Inoculum ${ }^{\mathrm{b}}$} & \multirow[b]{2}{*}{ Control $^{c}$} & \multicolumn{3}{|c|}{ Days after 1st inoculation ${ }^{\mathrm{d}}$} & \multirow{2}{*}{$\begin{array}{c}\begin{array}{c}\text { Days after 2nd } \\
\text { inoculation }\end{array} \\
3\end{array}$} \\
\hline & & & 3 & 5 & 7 & \\
\hline $\mathrm{ALT}$ & $\begin{array}{l}\text { Live DV } \\
\text { UV-DV } \\
\text { Mock }\end{array}$ & $25.7 \pm 10.4$ & $\begin{array}{l}38.3 \pm 16.2^{*} \\
37.2 \pm 4.1^{*} \\
30.4 \pm 1.7\end{array}$ & $\begin{array}{l}36.7 \pm 15.6^{* * *} \\
36.0 \pm 18.3 \\
29.3 \pm 9.9\end{array}$ & $\begin{array}{l}30.5 \pm 5.5 \\
27.0 \pm 7.1 \\
32.0 \pm 2.8\end{array}$ & $33.0 \pm 4.9^{*}$ \\
\hline AST & $\begin{array}{l}\text { Live DV } \\
\text { UV-DV } \\
\text { Mock }\end{array}$ & $43.3 \pm 5.4$ & $\begin{array}{l}67.1 \pm 28.0^{*} \\
64.8 \pm 5.2^{* *} \\
48.4 \pm 9.2\end{array}$ & $\begin{array}{l}94.8 \pm 32.3^{* *} \\
58.0 \pm 10.0 \\
35.3 \pm 19.7\end{array}$ & $\begin{array}{l}82.2 \pm 17.1^{* *} \\
63.0 \pm 7.1 \\
42.0 \pm 5.7\end{array}$ & $164.3 \pm 75.2^{* *}$ \\
\hline
\end{tabular}

${ }^{\text {a ALT }}$ and AST levels were determined by Abbott Alcyon 300i. The enzyme levels are presented as units per liter (U/L).

${ }^{\mathrm{b}}$ Mice were inoculated with live dengue virus (Live DV), UV-inactivated virus (UV-DV), or mock supernatant (mock).

${ }^{\mathrm{c}}$ Controls were normal mice without inoculation.

${ }^{\mathrm{d}}$ Sera were collected from mice at days 3,5 , and 7 after one inoculation and day 3 after second inoculation. Five to six mice were included in each experiment.

${ }^{*} P<0.05$, comparing the level of ALT or AST of live dengue virus, UV-inactivated dengue virus, or mock culture supernatant inoculated mice with that of control uninfected mice.

${ }^{*} P<<0.005$, comparing the level of ALT or AST of live dengue virus, UV-inactivated dengue virus, or mock culture supernatant inoculated mice with that of control uninfected mice. 

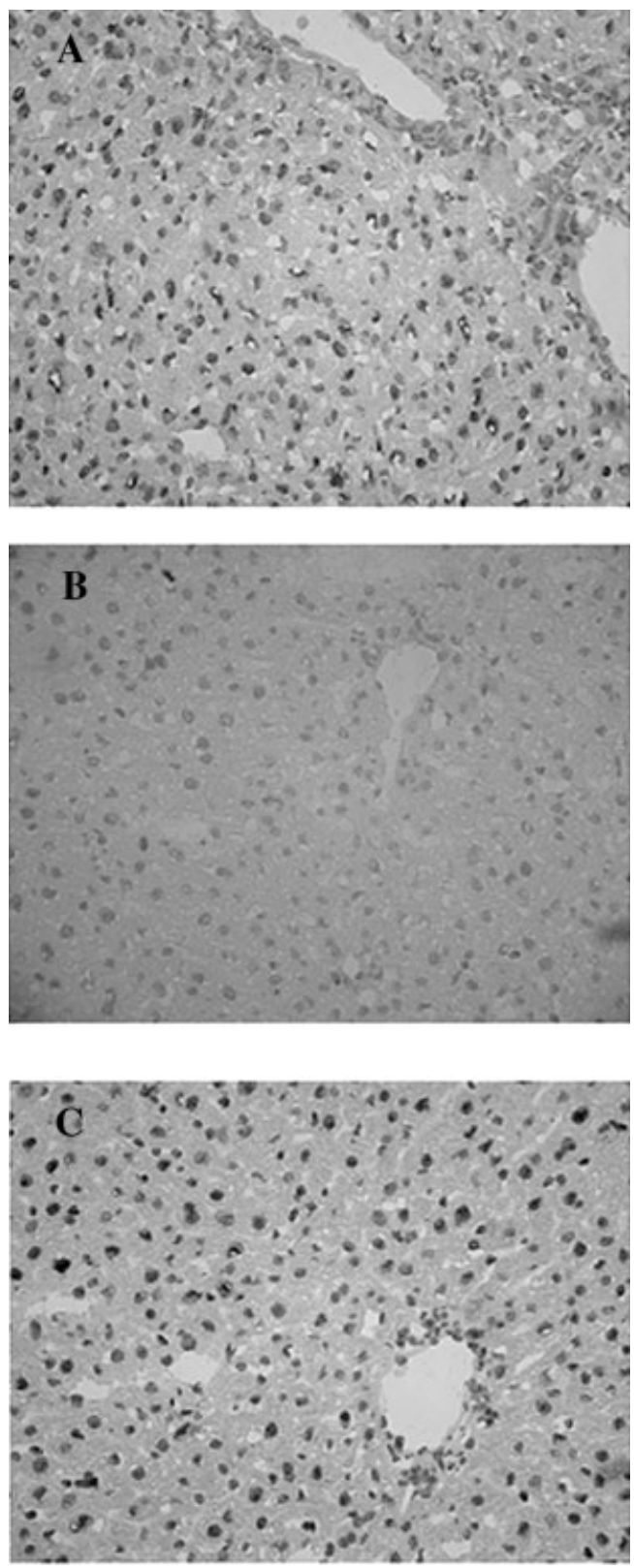

Fig. 8. Liver cell undergo apoptosis after dengue virus infection. DNA fragmentation was detected by in situ TUNEL staining. DNase I treated tissue was used as positive control (A). Uninfected normal (B) and dengue virus-infected (C) mouse liver sections were treated with FITC-conjugated TdT-mediated dUTP nick end labeling mixture and peroxidase-conjugated anti-FITC antibody. DAB was used as substrate and methyl green as counterstain.

remains to be investigated whether high IFN- $\gamma$ level is an indication of $\mathrm{T}$ cell activation or directly related to liver injury.

In summary, by injecting high titers of dengue virus serotype-2 hemorrhagic strain to immunocompetent C57BL/6 mice, a mouse model to study $\mathrm{T}$ cell activation is developed. As Rothman et al. pointed out that various immune mechanism(s) is important to different stages of dengue infection [Rothman and Ennis, 1999], the results of this study revealed the possibility that liver
TABLE III. Correlation Between IFN- $\gamma$ Production and Cellular Infiltration in the Liver

\begin{tabular}{lcc}
\hline Experiment & Infiltration scores $^{\mathrm{a}}$ & $\begin{array}{c}\text { IFN- } \gamma \text { produced by } \\
\text { spleen cells }(\mathrm{ng} / \mathrm{ml})^{\mathrm{b}}\end{array}$ \\
\hline I & ++ & 21.0 \\
& + & 12.4 \\
II & - & $2.8^{\mathrm{c}}$ \\
& ++ & 19.6 \\
& + & 7.2 \\
& - & $3.2^{\mathrm{c}}$ \\
\hline
\end{tabular}

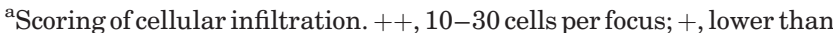
10 cells per focus; - , no significant infiltration.

${ }^{\mathrm{b}}$ Spleen cells were harvested from mice at 5 days after virus inoculation and stimulated with inactivated virus in vitro as described in materials and methods. Supernatants were collected at $24 \mathrm{hr}$ of incubation and IFN- $\gamma$ concentration was determined by ELISA.

${ }^{\text {c}}$ Spleen cells were collected from mice inoculated with inactivated virus.

injury in dengue is related to $\mathrm{CD} 8^{+} \mathrm{T}$ cell activation and infiltration.

\section{ACKNOWLEDGMENTS}

H.-C. Chen and S.-Y. Lai contributed equally to this manuscript. We are grateful to the excellent technical assistance provided by Miss M.-Y. Liao.

\section{REFERENCES}

An J, Kimura-Kuroda J, Hirabayashi Y, Yasui K. 1999. Development of a novel mouse model for dengue virus infection. Virology 263: $70-77$.

Bhamarapravati N. 1997. Pathology of dengue infections. Oxon, UK: Cab International, Inc. p 115.

Bhamarapravati N, Tuchinda P, Boonypaknavik V. 1967. Pathology of Thailand haemorrhagic fever: A study of 100 autopsy cases. Ann Trop Med Parasitol 61:500-510.

Burke DS, Nisalak A, Johnson D, Scott RM. 1988. A prospective study of dengue infections in Bangkok. Am J Trop Med Hyg 38:172-180.

Couvelard A, Marianneau P, Bedel C, Drouet MT, Vachon F, Henin D, Deubel V. 1999. Report of a fatal case of dengue infection with hepatitis: Demonstration of dengue antigens in hepatocytes and liver apoptosis. Human Pathol 30:1106-1110.

Deubel V, Kinney RM, Trent DW. 1986. Nucleotide sequence and deduced amino sequence of the structural proteins of dengue type 2 virus, Jamaica genotype. Virology 155:365-377.

Falgout B, Bray M, Schlesinger JJ, Lai CJ. 1990. Immunization of mice with recombinant vaccine virus expressing authentic dengue virus nonstructural protein NS1 protects against lethal dengue virus encephalitis. J Virol 64:4356-4363.

Green S, Pichyanghul S, Vaughn DW, Kalayanarooj S, Nimmannitya S, Nisalak A, Kurane I, Rothman AL, Ennis FA. 1999. Early CD69 expression on peripheral blood lymphocytes from children with dengue hemorrhagic fever. J Infect Dis 180:1429-1435.

Gubler DJ. 1988. Dengue. In: Monath TP, editor. Epidemiology of arthropod-borne viral disease. Boca Raton, FL: CRP Press, Inc. pp 233-260.

Gubler DJ. 1998. Dengue and dengue hemorrhagic fever. Clin Microbiol Rev 11:480-496.

Gubler DJ, Reed D, Rosen L, Hitchock JC. 1978. Epidemiologic, clinical, and virologic observations on dengue in the Kingdom of Tonga. Am J Trop Med Hyg 27:581-589.

Guzman MG, Kouri G. 2002. Dengue: And update. Lancet Infect Dis $1: 33-42$.

Hall WC, Crowell TP, Watts DM, Barros VL, Kruger H, Pinheiro F, Peters CJ. 1991. Demonstration of yellow fever and dengue antigens in formalin-fixed paraffin-embedded human liver by immunohistochemical analysis. Am J Trop Med Hyg 45:408-417. 
Halstead SB. 1970. Observations related to pathogenesis of dengue hemorrhagic fever. VI. Hypotheses and discussion. Yale J Biol Med 42:350-362.

Halstead SB. 1980. Dengue hemorrhagic fever-public health problem and a field for research. Bull WHO 58:1-21.

Halstead SB. 1988. Pathogenesis of dengue: Challenges to molecular biology. Science 239:476-481.

Harrigton LE, Galvan M, Baurn LG, Altman JD, Ahmed R. 2000. Differentiating between memory and effector CD8 T cells by altered expression of cell surface O-glycan. J Exp Med 191:1241-1246.

Huang KJ, Chen SC, Liu HS, Lin YS, Yeh TM, Liu CC, Lei HY. 2000. Manifestation of thrombocytopenia in dengue-2-virus-infected mice. J Gen Virol 8:2177-2182.

Huerre MR, Lan NT, Marianneau P, Hue NB, Khun H, Hung NT, Khen NT, Drouet MT, Huong VTQ, Ha DQ, Buisson Y, Deubel V. 2001. Liver histopathology and biological correlates in five cases of fatal dengue fever in Vietnamese children. Virchows Arch 438: $107-115$.

Innis BL. 1995. Dengue and dengue hemorrhagic fever. London, UK: Champman Hall, Inc. p 103.

Johnson AK, Roehrig JT. 1999. New mouse model for dengue virus vaccine testing. J Virol 73:783-786.

Kalayanarooj S, Vaughn DW, Nimmannitya S, Green S, Suntayakorn S, Kunentrasai N, Vitamitrachai W, Ratanachueke S, Kiapoloj S, Innis BL, Rothman AL, Nisalak A, Ennis FA. 1997. Early clinical and laboratory indicators of acute dengue illness. J Infect Dis 176: $313-321$.

Kangwanpong D, Bhamarapravati N, Lucia HL. 1995. Diagnosing dengue virus infection in archived autopsy tissues by means of the in situ PCR method: A case report. Clin Diagn Virol 3:165-172.

Kliks SC, Nisalak A, Bradndt WE, Wahl L, Burke DS. 1989. Antibodydependent enhancement of dengue virus growth in human monocytes as a risk for dengue hemorrhagic fever. Am J Trop Med Hyg 40:444-451.

Kuo CH, Tai DI, Chang-Chien CS, Lan CK, Chiou SS, Liaw YF. 1992. Liver biochemical tests and dengue fever. Am J Trop Med Hyg 47:265-270.

Kurane I, Innis BL, Nisalak A, Hoke C, Nimmeannitya S, Meager A, Ennis FA. 1989. Human T cell responses to dengue virus antigens. proliferative responses and interferon gamma production. J Clin Invest 83:506-513.

Kurane I, Innis BL, Nimmeannitya S, Nisalak A, Meager A, Janus J, Ennis FA. 1991. Activation of T lymphocytes in dengue virus infections. High levels of soluble interleukin 2 receptor, soluble CD4, soluble CD8, interleukin 2 , and interferon- $\gamma$ in sera of children with dengue. J Clin Invest 88:1473-1480.

Lanciotti RS, Calisher CH, Gubler DJ, Chanfm GJ, Vorndam AV. 1992. Rapid detection and typing of dengue viruses from clinical samples by using reverse transcriptase-polymerase chain reaction. J Clin Microbiol 30:545-551.

Lei HY, Yeh TM, Liu HS, Lin YS, Chen SH, Liu CC. 2001. Immunopathogenesis of dengue virus infection. J Biomed Sci 8: 377-388

Lin YL, Liao CL, Chen LK, Yeh CT, Liu CI, Ma SH, Huang YY, Huang YL, Kao CL, King CC. 1998. Study of dengue virus infection in SCID mice engrafted with human K562 cells. J Virol 72:9729-9737.

Lin YL, Liu CC, Lei HY, Yeh TM, Lin YS, Chen RMY, Liu HS. 2000a. Infection of five human liver cell lines by dengue-2 virus. J Med Virol 60:425-431.

Lin YL, Liu CC, Chung JI, Lei HY, Yeh TM, Lin YS, Hung YH, Liu HS. 2000a. Involvement of oxidative stress, NF-IL-6 and RANTES expression in dengue-2 virus infected human liver cells. Virology 276:114-126.

Livingston PG, Kurane I, Dai LC, Okamato Y, Lai CJ, Men R, Karaki S, Takiguchi M, Ennis FA. 1995. Dengue virus-specific, HLA-B35restricted, human $\mathrm{CD}^{+}$cytotoxic T lymphocyte (CTL) clones. Recognition of NS3 amino acids 500 to 508 by CTL clones of two different serotype specificities. J Immunol 154:1287-1295.

Monath TP. 1994. Dengue: The risk to developed and developing countries. Proc Natl Acad Sci USA 91:2395-2400.

Monath B, Patwari AK, Anand VK. 2000. Hepatic dysfunction in childhood dengue infection. J Trop Pediatr 46:40-43.

Nguyen TL, Nguyen TH, Tieu NT. 1997. The impact of dengue haemorrhagic fever on liver function. Res Virol 148:273-277.

Regner M, Lobigs M, Blanden R, Milburn P, Mullbacher A. 2001. Antiviral cytotoxic $\mathrm{T}$ cells cross-reactively recognize disparate peptide determinants from related viruses but ignore more similar self- and foreign-determinants. J Immunol 166:3820-3828.

Rosen L. 1977a. The Emperor's new clothes revisited, or reflections on the pathogenesis of dengue hemorrhagic fever. Am J Trop Med Hyg 26:337-343

Rosen L. 1977b. Dengue: An overview. Sydney, Australia: Academic Press, Inc. pp 484-493.

Rosen L, Khin MM, Tin U. 1989. Recovery of virus from the liver of children with fatal dengue. Reflections on the pathogenesis of the disease and its possible analogy with that of yellow fever. Res Virol 140:351-360.

Rothman AL, Ennis FA. 1999. Immunopathogenesis of dengue hemorrhagic fever. Virology 257:1-6.

Russell PK, Udomsakdi S, Halstead SB. 1967. Antibody response in dengue and dengue hemorrhagic fever. Jpn J Med Sci Biol 20:103108.

Sangkawibha N, Rojanasuphot S, Ahandrink S, Viriyapongse S, Jatanasen S, Salitul V, Phanthumachinda B, Halstead SB. 1984 Risk factors in dengue shock syndrome: A prospective epidemiologic study in Rayong, Thailand. Am J Epidemiol 120:653-669.

Schepers K, Toebes M, Sotthewes G, Vyth-Dreese FA, Dellemijn TAM Melief CJM, Ossendorp F, Schumacher TNM. 2002. Differential kinetics of antigen-specific $\mathrm{CD} 4^{+}$and $\mathrm{CD} 8^{+} \mathrm{T}$ cell response in the regression of retrovirus-induced sarcomas. J Immunol 169:31913199.

Testi R, Phillips JH, Lanier LL. 1989. T cell activation via Leu-23 (CD69). J Immunol 143:1123-1128.

Wahid SF, Sanusi S, Zawawi MM, Ali RA. 2000. A comparison of the pattern of liver involvement in dengue hemorrhagic fever with classic dengue fever. South Asian J Trop Med Public Health 31: 259-263.

Wang WK, Lee CN, Kao CL, Lin YL, King CC. 2000. Quantitative competitive reverse transcription-PCR for quantification of dengue virus RNA. J Clin Microbiol 38:3306-3310.

Wang WK, Shung TL, Tsai YC, Kao CL, Chang SM, King CC. 2002 Detection of dengue virus replication in peripheral blood mononuclear cells from dengue virus type 2 -infected patients by a reverse transcription-real-time PCR assay. J Clin Microbiol 40:4472-4478.

Wu SJL, Hayes CG, Dubois DR, Windheuser MG, Kang YH, Watts DM, Sieckmann DG. 1995. Evaluation of the severe combined immunodeficient (SCID) mice as a animal model for dengue viral infection. Am J Trop Med Hyg 52:468-476.

Zivna I, Green S, Vaughn DW, Kalayanarooj S, Stephens HAF, Chandananyingyong D, Nisalak A, Ennis FA, Rothman AL. 2002. $\mathrm{T}$ cell responses to an HLA-B*07-restricted epitope on the dengue NS3 protein correlate with disease severity. J Immunol 168:5959_ 5965 . 